\title{
Faktor - Faktor yang Berpengaruh Terhadap Keputusan Pemilihan Daging Ayam Broiler Sebagai Konsumsi Rumah Tangga di Surakarta (Studi Kasus di Kelurahan Tegalharjo Kecamatan Jebres)
}

\author{
E. T. Rahayu*, R. Dewanti, M. A. Long \\ Program Studi Peternakan, Fakultas Pertanian, Universitas Sebelas Maret
}

\begin{abstract}
ABSTRAK
Penelitian ini bertujuan untuk mengetahui faktor - faktor yang berpengaruh terhadap keputusan pemilihan daging ayam broiler untuk konsumsi Rumah tangga di Surakarta. Penelitian ini merupakan studi kasus yang dilakukan di salah satu kelurahan terpadat yaitu kelurahan Tegalharjo, Kecamatan Jebres, Kota Surakarta. Penelitian ini dilaksanakan pada bulan November - Desember 2015. Metode dasar yang digunakan dalam penelitian ini adalah metode deskriptif kuantitatif dengan teknik survei terhadap keluarga/rumah tangga di Kelurahan Tegalharjo Kecamatan Jebres, Kota Surakarta. Teknik Pengambilan Sampel dilakukan dengan metode Purposive Sampling dengan jumlah responden sebanyak 86 orang. Data primer diperoleh dari wawancara dengan alat bantu kuisioner. Data Sekunder diperoleh dari Badan Pusat Statistik (BPS) Kota Surakarta, Kecamatan Jebres dan Kelurahan Tegalharjo. Analisis data yang digunakan adalah analisis deskriptif, uji validitas, uji reliabilitas, uji multikolinearitas, uji heteroskedastisitas dan uji regresi linear berganda. Hasil Penelitian menunjukan bahwa instrumen dinyatakan valid karena $\mathrm{r}$ hitung $>\mathrm{r}$ tabel serta reliabel karena hasil Alpha Cronbach untuk setiap sub variabel pada kisaran angka $0,761-0,873$, data penelitian berdistribusi normal dengan nilai signifikansi tiap variabel $>0,05$, hasil uji regresi linear berganda menunjukkan setiap variabel berpengaruh signifikan terhadap konsumsi daging ayam broiler kecuali variabel faktor kekayaan keluarga $\left(\mathrm{X}_{2}\right)$, dengan nilai Adjusted $\mathrm{R}^{2}$ sebesar 0,731 . Simpulan dari penelitian ini bahwa faktor ekonomi dan sosial secara keseluruhan berpengaruh terhadap tingkat konsumsi daging ayam broiler pada rumah tangga di Kota Surakarta.
\end{abstract}

Kata Kunci: Konsumsi, Daging ayam broiler, Rumah tangga, Faktor ekonomi

\section{Factors Affecting the Decision to Choice Broiler Meat for Household Consumption in Surakarta (Case Study in Tegalharjo Jebres)}

\begin{abstract}
This study aims to determine the factors that influence the decision on the selection of broiler for household consumption in Surakarta. This study is a case study conducted in one of the densest urban village of Tegalharjo, Jebres, Surakarta. This research was conducted in November - December 2015. The basic method used in this research is quantitative descriptive method with survey technique to household / household in Tegalharjo Village, Jebres, Surakarta. Sampling technique is done by Purposive Sampling method with 86 respondents. Primary data was obtained from interview with questionnaire tool. Secondary data obtained from the Central Bureau of Statistics (BPS) Surakarta, Jebres and Tegalharjo. Data analysis used was descriptive analysis, validity test, reliability test, normality test, linearity test, multicollinearity test, heteroscedasticity test and multiple linear regression test. The result of research shows that the instrument is valid because $r$ count $>r$ table and reliable because of Alpha Cronbach result for each sub variable in the range 0,761 - 0,873, research data is normal distribution with significance value of each variable $>0,05$, result of multiple linear regression test show each variable has significant effect on broiler consumption except family wealth factor variable (X2), with value of Adjusted R2 equal to 0,731. Conclusion from this research was that the economic and social factors as a whole affect the level of consumption of broiler in the household in Surakarta.
\end{abstract}

Keywords: Consumption, Broiler chicken, Household, Economic factor

\section{PENDAHULUAN}

Salah satu sumber protein hewani untuk mencukupi kebutuhan pangan masyarakat adalah sumber protein yang berasal dari ayam broiler. Produk daging ayam broiler merupakan komoditas pangan yang unggul sebab daging ayam broiler banyak kegunaan dan manfaatnya untuk menunjang kebutuhan gizi masyarakat. Daging ayam broiler dapat dikonsumsi dan diterima oleh semua golongan masyarakat dan agama sebagai makanan yang memiliki nilai gizi yang tinggi. Berdasarkan informasi

\footnotetext{
*Penulis Korespondensi: Endang Tri Rahayu

Alamat: Jl. Ir. Sutami 36

E-mail: e_trirahayu@yahoo.co.id
}

dari Dirjen Peternakan dan Kesehatan Hewan (2012), didalam 100 gram daging ayam terkandung kalori sebesar $302 \mathrm{kal}$, lemak sebesar 25 gram, dan protein sebesar 22 gram serta mengandung kalsium, fosfor dan besi masing-masing sebesar $13 \mathrm{mg}, 190 \mathrm{mg}$ dan $1,5 \mathrm{mg}$.

Konsumsi daging di Indonesia cenderung mengalami peningkatan dalam kurun waktu tahun 2009 - 2012. Hal ini didasarkan pada data dari BPS tahun 2013 dimana konsumsi daging sapi mengalami sedikit dinamika yaitu $0,313 \mathrm{~kg} / \mathrm{kapita}, \quad 0,365$ $\mathrm{kg} / \mathrm{kapita}, \quad 0,417 \mathrm{~kg} / \mathrm{kapita}, 0,365 \mathrm{~kg} / \mathrm{kapita}$ dalam kurun waktu tahun 2009 - 2012. Konsumsi daging ayam berbeda dengan konsumsi daging sapi yang mana cenderung mengalami peningkatan lebih pesat 
dalam kurun waktu yang sama, yaitu 3,597 kg/kapita, 4,172 kg/kapita, 4,276 kg/kapita, dan 4,015 kg/kapita.

Beberapa faktor yang mempengaruhi seorang kepala keluarga memilih daging ayam sebagai konsumsi rumah tangga adalah faktor ekonomi dan faktor sosial. Makin tinggi tingkat pendapatan akan meningkatkan kemampuan rumah tangga untuk membeli kebutuhan protein menjadi semakin besar serta ada kecenderungan untuk memenuhi kebutuhan yang lebih berkualitas. Harga barang komplementer dan subtitusi seperti minyak dan telur juga turut menjadi pertimbangan seseorang apabila akan membeli daging ayam. Faktor-faktor sosial yang paling berpengaruh terhadap besarnya konsumsi daging ayam adalah faktor sosial budaya masyarakat seperti berubahnya pola kebiasaan makan, perubahan gaya hidup karena ingin meniru kelompok masyarakat lain yang dianggap lebih hebat.

Kelurahan Tegalharjo Kecamatan Jebres Kota Surakarta merupakan wilayah perkotaan dengan kondisi padat penduduk yakni berjumlah 1.575 Jumlah KK dan 5.178 Jiwa. Kondisi masyarakat kelurahan Tegalharjo memiliki heterogenitas yang cukup tinggi baik dari segi pendidikan, ekonomi, sosial dan budaya berdasarkan data di atas. Kondisi tersebut menunjukkan masyarakat tegalharjo memiliki ciri sebuah masyarakat perkotaan yang dinamis dan heterogen. Hal ini menarik untuk dilakukan penelitian yaitu tentang faktor-faktor yang mempengaruhi konsumsi daging ayam pada rumah tangga di Kelurahan Tegalharjo Kecamatan Jebres Kota Surakarta.

\section{MATERI DAN METODE}

Penelitian ini dilaksanakan pada bulan november sampai Desember 2015 di Kelurahan Tegalharjo, Kecamatan Jebres, Kota Surakarta. Metode dasar yang digunakan dalam penelitian ini adalah metode deskriptif kuantitatif. Pelaksanaan penelitian menggunakan metode survei terhadap keluarga/ rumah tangga di Kelurahan Tegalharjo Kecamatan Jebres, Kota Surakarta.

Metode pengambilan sampel dilakukan secara sengaja (purposive sampling) dengan jumlah sampel yang diambil dalam penelitian ini adalah 86 responden atau $10 \%$ dari total jumlah KK di RW 1, RW 2, dan RW 6 yang berjumlah 856 KK. Pengambilan sampel bagi masing-masing RW menurut Mardikanto (2001) dilaksanakan secara proporsional. Data yang sudah terkumpul dianalisis secara deskriptif.

\section{Uji Validitas}

Validitas adalah tingkat keandalan dan kesahihan alat ukur yang digunakan. Instrumen dikatakan valid berarti menunjukkan alat ukur yang dipergunakan untuk mendapatkan data itu valid atau dapat digunakan untuk mengukur apa yang seharusnya diukur (Sugiyono, 2004).

\section{Uji Reliabilitas}

Uji reliabelitas dilakukan untuk mengetahui sejauh mana suatu instrument dapat memberikan hasil yang relatif sama bila dilakukan pengukuran kembali pada subyek yang sama. Rumus yang digunakan adalah rumus Alpha Cronbach (Arikunto, 2003)

\section{Uji Mulikolinearitas}

Uji multikolinieritas digunakan untuk menguji apakah terdapat korelasi antara variabel independen dalam model regresi (Santoso, 2004). Multikolinieritas dapat dilihat dari nilai tolerance dimana nilai yang terbentuk harus diatas 10 sedangkan Variance Inflation Factor (VIF) dimana nilai yang terbentuk harus kurang dari 10 agar tidak terjadi multi.

\section{Uji Heterokedastisitas}

Uji Heterokedastisitas bertujuan untuk menguji apakah dalam sebuah model regresi terjadi ketidaksamaan varians dari residual pada satu pengamatan ke pengamatan yang lain. Jika terdapat varians, maka dijumpai gejala heterokedastisitas (Santoso, 2004).

\section{Uji Regresi Linear Berganda}

Penelitian ini menggunakan uji regresi berganda. Regresi berganda (multivariate regression) merupakan suatu model di mana variabel terikat tergantung pada dua atau lebih variabel bebas.

Analisa ini untuk mengetahui hubungan antara permintaan daging ayam broiler dengan faktor-faktor yang mempengaruhinya. Hubungan ini dirumuskan dengan bentuk persamaan regresi linier berganda sebagai berikut :

$$
Y=a+b_{1} X_{1}+b_{2} X_{2}+b_{3} X_{3}+b_{4} X_{4}+b_{5} X_{5}+b_{6} X_{6}-e
$$

Keterangan :

$$
\begin{aligned}
& \text { Y } \quad \text { Pemilihan daging ayam broiler } \\
& \text { untuk konsumsi keluarga } \\
& \begin{array}{lll}
\text { a } & : & \text { Konstanta } \\
\mathrm{X}_{1}: & \text { Pendapatan Rumah Tangga } \\
\mathrm{X}_{2} & : & \text { Kekayaan Rumah Tangga } \\
\mathrm{X}_{3} & : & \text { Harga } \\
\mathrm{X}_{4} & : & \text { Pola Makan } \\
\mathrm{X}_{5} & : & \text { Sosial Budaya } \\
\mathrm{X}_{6} & : & \text { Pengetahuan Gizi } \\
\varepsilon & : & \text { Variabel Pengganggu }
\end{array}
\end{aligned}
$$

\section{HASIL DAN PEMBAHASAN}

\section{Keadaan Umum Lokasi Penelitian}

Kota Surakarta merupakan salah satu kota yang perkembangan penduduknya pesat, dengan luasan 44,04 $\mathrm{Km}^{2}$ dan Jumlah penduduk 5.453.653 Jiwa pada tahun 2012 dengan pertumbuhan penduduk 1.6\% per tahun. 
Tabel 1. Usia responden

\begin{tabular}{ccc}
\hline \hline Kelompok Usia (Tahun) & Jumlah Responden & Persentase (\%) \\
\hline $18-34$ & 36 & 42,35 \\
$35-54$ & 42 & 49,41 \\
$>55$ & 7 & 8,24 \\
\hline Jumlah & 85 & 100 \\
\hline
\end{tabular}

Sumber: Data Primer terolah, 2015

Jumlah penduduk di kelurahan Tegalharjo adalah sebagai berikut: Jumlah kepala keluarga 1.574 KK, jumlah Laki-laki 2.546 orang, jumlah perempuan 2.632 orang, jumlah total 5.178 orang.

\section{Karakteristik Responden}

Karakteristik responden pada penelitian ini adalah mengenai beberarapa informasi yang berkaitan dengan tema penilitian, yaitu faktor - faktor yang mempengaruhi konsumsi daging ayam broiler. Beberapa informasi yang disajikan adalah mengenai karakteristik responden yaitu usia responden, jumlah anak, pendidikan terakhir, Pekerjaan dan pendapatan keluarga, serrta kepemilikan rumah dan kendaraan bermotor. Tabel 1 menunjukkan usia responden.

Usia responden pada penelitian ini mayoritas masih dalam usia produktif dimana usia 18 - 34 tahun sebesar 42,35 \% dan usia 35 - 54 sebesar 49,41 persen. Pada usia produktif seorang Ibu rumah tangga atau kepala rumah tangga masih mengatur sepenuhnya pengeluaran keluarga karena pada kisaran usia tersebut diprediksi setiap anggota keluarga belum sepenuhnya lepas dari tanggung jawab nafkah kedua orang tua.

Jumlah anggota keluarga merupakan satu aspek yang selalu menjadi pertimbangan apabila seseorang akan membelanjakan uangnya untuk konsumsi keluarga. Jumlah anggota keluarga akan mempengaruhi jumlah pengeluaran secara menyuluruh suatu rumah tangga. Responden penelitian ini mayoritas memliki 1-3 anak yaitu sebesar 53,49 \%, yang berarti pada jumlah yang sedang paling mendominasi. Jumlah anak responden dapat dilihat pada Tabel 2.

Mayoritas pendidikan responden pada penelitian ini adalah lulusan SMA. Pendidikan sangat berpengaruh terhadap tingkat pengetahuan seorang Ibu atau Kepala rumah tangga terhadap pemenuhan asupan gizi keluarga.

Pendapatan rumah tangga amat besar pengaruhnya terhadap tingkat konsumsi. Makin baik tingkat pendapatan, tingkat konsumsi makin tinggi, karena ketika tingkat pendapatan meningkat, kemampuan rumah tangga untuk membeli aneka kebutuhan konsumsi menjadi semakin besar (Hakim, 2008). Responden pada penelitian ini memiliki keragaman tingkat pendapatan mulai dari yang rendah sampai tinggi. Dominasi tingkat pendapatan responden berada pada tingkat menengah ke bawah.

Seseorang yang memiliki banyak aset riil cenderung memiliki pengeluaran konsumsi yang tinggi. Kepemilikan rumah dan kendaraan bermotor merupakan beberapa hal yang menjadi tolok ukur masyarakat mengenai kekayaan seseorang atau sebuah rumah tangga. Data diatas menerangkan bahwa responden pada penelitian kali ini mayoritas pada kalangan menengah apabila dilihat dari kepemilikan tempat tinggal dan kendaraan bermotor.

\section{Pengujian Instrumen Penelitian (Uji Validitas dan Uji Realibilitas)}

Validitas adalah tingkat keandalan dan kesahihan alat ukur yang digunakan. Instrumen dikatakan valid berarti menunjukkan alat ukur yang dipergunakan untuk mendapatkan data itu valid atau dapat digunakan untuk mengukur apa yang seharusnya diukur (Sugiyono, 2004). Suatu butir pertanyaan dikatakan valid jika nilai $r$

hitung $\geq \mathrm{r}$ tabel. Nilai $\mathrm{r}$ tabel diperoleh melalui $\mathrm{df}$ (degree of freedom $)=\mathrm{n}-2$ dimana $\mathrm{n}$ merupakan banyaknya responden (Muhidin, 2007). Uji validitas kuisioner penelitian ini menggunakan 20 responden dan mengambil responden dari Kepala Keluarga (KK) di wilayah RW 1,RW 2, RW 6 Kelurahan Tegalharjo Kecamatan Jebres, dengan demikian df dalam penelitian ini adalah 20-2 = 18 dan $\alpha=5 \%$ dan diperoleh nilai tabel koefisien korelasi sebesar 0, 444 menunjukan bahwa nilai $r$ hitung $\geq r$ tabel sehingga semua butir pertanyaan berarti valid.

Uji reliabelitas dilakukan untuk mengetahui sejauh mana suatu instrument dapat memberikan hasil yang relative sama bila dilakukan pengukuran kembali pada subyek yang sama. Hasil pengujian menunjukan hasil angka koefisien Alpha Cronbach untuk setiap sub variable pada kisaran angka 0,761 0,873 yang berarti realiabel.

Tabel 2. Jumlah anak responden

\begin{tabular}{ccc}
\hline \hline $\begin{array}{c}\text { Kelompok Jumlah Anak } \\
\text { (Orang) }\end{array}$ & Jumlah Responden (Orang) & Persentase (\%) \\
\hline Belum Punya & 7 & 8,14 \\
$1-3$ & 46 & 53,49 \\
$4-6$ & 29 & 33,72 \\
$>6$ & 4 & 4,65 \\
\hline Jumlah & 86 & 100 \\
\hline
\end{tabular}

Sumber: Data Primer terolah, 2015 
Tabel 3. Pendidikan Terakhir

\begin{tabular}{ccc}
\hline \hline Pendidikan Terakhir & Jumlah Responden (Orang) & Persentase (\%) \\
\hline SD & 4 & 4,65 \\
SMP & 9 & 10,46 \\
SMA & 43 & 50 \\
Sarjana/Diploma & 19 & 22,09 \\
S2/S3 & 11 & 12,79 \\
\hline Jumlah & 86 & 100 \\
\hline
\end{tabular}

\section{Analisis Deskriptif Tiap Variabel}

Deskripsi variabel menggambarkan tanggapan responden mengenai faktor pendapatan keluarga, kekayaan keluarga, harga, pola makan, sosial budaya dan pengetahuan tentang gizi terhadap tingkat konsumsi daging ayam broiler pada ibu-ibu rumah tangga di Kelurahan Tegalharjo Kecamatan Jebres Kota Surakarta. Data hasil penelitian kemudian dikategorikan ke dalam tiga kelompok yaitu tinggi, sedang dan rendah. Hasil kategorisasi tersebut disajikan pada Tabel 6 .

\section{Uji Multikolinieritas}

Uji multikolinieritas dilakukan untuk mengetahui besarnya interkorelasi antar dimensi bebas dalam penelitian ini. Jika terjadi korelasi, maka dinamakan terdapat masalah multikolinieritas. Untuk mendeteksi ada tidaknya multikolinieritas dapat dilihat pada nilai tolerance dan VIF. Apabila nilai tolerancedi atas 0,1 dan nilai VIF di bawah 10 maka tidak terjadi multikolinieritas.Penelitian ini menunjukan bahwa semua dimensi yang meliputi : pendapatan keluarga, kekayaan keluarga, harga, pola makan, sosial budaya dan pengetahuan gizi mempunyai nilai toleransi di atas 0,1 dan nilai VIF di bawah 10, sehingga dapat disimpulkan bahwa model regresi pada penelitian ini tidak terjadi multikolinieritas.

\section{Uji Heterokedastisitas}

Pengujian heterokedatisitas bertujuan untuk menguji apakah dalam model regresi terjadi ketidaksamaan varian dari residual satu pengamatan ke pengamatan yang lain. Model regresi yang baik adalah tidak terjadi heterokedastisitas dan untuk mengetahui adanya heterokedastisitas dengan menggunakan uji Glejser. Jika dimensi independen tidak signifikan secara statsitik dan tidak mempengaruhi dimensi dependen, maka ada indikasi tidak terjadi heterokedastisitas. Pada penelitian ini menunjukan bahwa terdapat satu variabel yang terjadi heterokedastisitas yaitu pendapatan keluarga dengan nilai signifikansi $0,00($ sig< $<0,005)$.

\section{Uji Regresi Linear Berganda}

Pengujian hipotesis dalam penelitian ini bertujuan untuk membutktikan hipotesis yang telah diajukan apakah variabel ekonomi (yang meliputi faktor pendapatan keluarga, kekayaan keluarga, harga) dan variabelsosial (yang meliputi faktor pola makan, sosial budaya, pengetahuan gizi) berpengaruh terhadap tingkat konsumsi daging ayam broilerpada ibu rumah tangga kelurahan Tegalharjo kecamatan Jebres Kota Surakarta. Analisis data yang digunakan untuk pengujian hipotesis dalam penelitian ini adalah analisis regresi berganda. Di bawah ini akan dibahas hasil analisis regresi berganda yang dilakukan dengan menggunakan program SPSS 19.00 for Windows. Hasil uji regresi berganda dapat dilihat pada Tabel 10 dengan model regresi linear berganda sebagai berikut :

$$
\begin{gathered}
\mathrm{Y}=6,959+0,584 \mathrm{X}_{1}+0,20 \mathrm{X}_{2}-0,548 \mathrm{X}_{3}+ \\
0,238 \mathrm{X}_{4}+0,174 \mathrm{X}_{5}+0,262 \mathrm{X}_{6}+\mathrm{e}
\end{gathered}
$$

Hasil penelitian menunjukkan bahwa factor pendapatan keluarga $\left(\mathrm{X}_{1}\right)$ berpengaruh positif terhadapkeputusan memilih daging ayam broiler pada Kepala Rumah Tangga di Kelurahan Tegalharjo Kecamatan Jebres Kota Surakarta. Faktor pendapatan keluarga diperoleh nilai t hitung sebesar sebesar 6,164 dan $\mathrm{t}$ tabel 1,671 $(\mathrm{df}=85)$ dengan tingkat signifikansi 0,000 ; karena $\mathrm{t}$ hitung $>\mathrm{t}$ tabel $(6,164>1,671)$, signifikansi lebih kecil dari $0,05(0,000<0,05)$, dan koefisien regresi mempunyai nilai positif sebesar 0,584; maka hipotesis yang menyatakan bahwa "faktor pendapatan keluarga berpengaruh positif terhadap tingkat konsumsi daging ayam broiler" adalah terbukti.

Menurut Lipsey (1995), faktor pertama yang mempengaruhi perilaku pembelian adalah penurunan harga suatu jenis barang. Penurunan harga suatu barang akan mempengaruhi rumah tangga melalui dua

Tabel 4. Pendapatan keluarga responden

\begin{tabular}{ccc}
\hline \hline Pendapatan Keluarga (Rp) & $\begin{array}{c}\text { Jumlah Keluarga Responden } \\
(\mathrm{KK})\end{array}$ & Persentase (\%) \\
\hline Kurang dari Rp. 1.000 .000 & 15 & 17,44 \\
$1.000 .000-2.500 .000$ & 38 & 44,19 \\
$2.500 .000-4.000 .000$ & 24 & 27,91 \\
Lebih dari Rp. 4.000 .000 & 9 & 10,46 \\
\hline Jumlah & 86 & 100 \\
\hline Sumber: Data Primer terolah, 2015 & &
\end{tabular}


Tabel 5. Status kepemilikan rumah responden

\begin{tabular}{|c|c|c|}
\hline Status Kepemilikan Rumah & $\begin{array}{l}\text { Jumlah Keluarga Responden } \\
(\mathrm{KK})\end{array}$ & Persentase (\%) \\
\hline Sewa & 18 & 20,93 \\
\hline Milik Sendiri & 46 & 53,49 \\
\hline Milik Orang Tua & 14 & 16,28 \\
\hline Menumpang Kerabat & 8 & 9,30 \\
\hline Jumlah & 86 & 100 \\
\hline \multicolumn{3}{|l|}{$\begin{array}{c}\text { Kepemilikan Kendaraan } \\
\text { Bermotor }\end{array}$} \\
\hline Tidak Memiliki & 12 & 13,95 \\
\hline Sepeda Motor & 48 & 55,81 \\
\hline Mobil & 11 & 12,79 \\
\hline Sepeda Motor dan Mobil & 15 & 17,45 \\
\hline Jumlah & 86 & 100 \\
\hline
\end{tabular}

Sumber : Data Primer terolah, 2015

cara. Pertama, harga relatif akan berubah sehingga rumah tangga terdorong untuk membeli lebih banyak, barang tersebut karena harganya lebih murah. Kedua, pendapatan riil rumah tangga meningkat, karena mereka bisa membeli lebih banyak semua jenis komoditi. Pertambahan pendapatan riil ini memberikan dorongan untuk membeli jumlah yang berbeda dari seluruh jenis komoditi.

Pilihan terhadap suatu produk sangat di pengaruhi oleh keadaan ekonomi seseorang yang dimaksud dengan keadaan ekonomi antara lain adalah pendapatan. (Kotler, 1994). Pendapatan berkaitan dengan kemampuan dan daya beli konsumen, pendapatan juga merupakan faktor penentu terhadap kualitas dan kuantitas makanan yang akan di konsumsi (Berg, 1986).

Faktor kekayaan keluarga $\left(\mathrm{X}_{2}\right)$ tidak berpengaruh positif terhadap keputusan memilih daging ayam broiler sebagai konsumsi Rumah Tangga di Kelurahan Tegalharjo Kecamatan Jebres Kota Surakarta. Hal ini dibuktikan dengan hasil statistik uji $\mathrm{t}$ untuk faktor kekayaan keluarga diperoleh nilai $\mathrm{t}$ hitung sebesar 0,180 dan $t$ tabel 1,671 $(\mathrm{df}=85)$ dengan tingkat signifikansi 0,857 ; karena $\mathrm{t}$ hitung $<\mathrm{t}$ tabel $(0,180<1,671)$, signifikansi lebih besar dari 0,05 $(0,857>0,05)$, dan koefisien regresi mempunyai nilai positif sebesar 0,020; maka hipotesis yang menyatakan faktor kekayaan keluarga berpengaruh terhadap pemilihan daging ayam broiler pada kepala keluarga di Kelurahan Tegalharjo, Jebres Kota Surakarta Tidak Terbukti, sehingga dapat disimpulkan bahwa "faktor kekayaan keluarga tidak berpengaruh terhadap keputusan memilihdaging ayam broiler".

Penyebab tidak berpengaruhnya kekayaan keluarga keputusan memilih daging ayam broiler sebagai konsumsi Rumah Tangga di Kelurahan Tegalharjo Kecamatan Jebres Surakarta di duga karena semakin bertambahnya pendapatan riil ini memberikan dorongan untuk membeli jenis yang berbeda dari seluruh jenis komoditi. Menurut Berg (1986), kekayaan merupakan faktor penentu terhadap kualitas dan kuantitas makanan yang akan di konsumsi. Rumah tangga yang memiliki kekayaan tinggi lebih mementingkan kualitas bahan makanan yang di beli daripada kuantitas, mereka merasakan bahwa ayam broiler seringkali memiliki kandungan antibiotik yang dapat menyebabkan munculnya beberapa penyakit oleh karenaitu mereka lebih memilih daging sapi, ikan air tawar ataupun ikan laut.Faktor harga $\left(\mathrm{X}_{3}\right)$ berpengaruh positif terhadap keputusan memilih daging ayam broiler sebagai konsumsi Rumah Tangga di Kelurahan Tegalharjo Kecamatan Jebres Kota Surakarta. Hal ini dibuktikan dengan hasil statistik uji $t$ untuk faktor harga diperoleh nilai $\mathrm{t}$ hitung sebesar 4,939 dan t tabel 1,671 (df=85) dengan tingkat signifikansi 0,000 ; karena $\mathrm{t}$ hitung $>\mathrm{t}$ tabel $(4,939>1,671)$, signifikansi lebih kecil dari $0,05(0,000<0,05)$, dan koefisien regresi mempunyai nilai positif sebesar 0,548 ; maka dapat disimpulkan bahwa faktor harga berpengaruh positif terhadap keputusan memilih daging ayam broiler.

Harga daging ayam broiler tersebut menentukan jumlah daging ayam yang diminta oleh konsumen. Semakin rendah harga suatu barang maka permintaan terhadap barang tersebut akan semakin banyak. Begitu pula sebaliknya, semakin tinggi harga suatu barang maka semakin sedikit permintaan terhadap barang tersebut (Lipsey et al., 1995). Lipsey et al. (1995) menyatakan bahwa selain harga barang itu sendiri, permintaan juga dipengaruhi oleh harga barang substitusi (pengganti) dan harga barang komplementer (pelengkap). Saat terjadi peningkatan harga suatu barang, konsumen cenderung mengkonsumsi produk lain dengan fungsi yang sama.

Faktor pola makan $\left(\mathrm{X}_{4}\right)$ berpengaruh positif terhadap keputusan memilih daging ayam broiler sebagai konsumsi Rumah Tangga di Kelurahan Tegalharjo Kecamatan Jebres Kota Surakarta. Hal ini dibuktikan dengan hasil statistik uji t untuk faktor pola makan diperoleh nilai t hitung sebesar 3,282 dan $\mathrm{t}$ tabel 1,671 (df=85) dengan tingkat signifikansi 0,002 ; karena $\mathrm{t}$ hitung $>\mathrm{t}$ tabel $(3,282>1,671)$, signifikansi lebih kecil dari $0,05(0,002<0,05)$, dan 
Tabel 6. Kategorisasi faktor-faktor yang mempengaruhi konsumsi daging ayam broiler

\begin{tabular}{|c|c|c|c|c|}
\hline Kategori variabel & Kategori & Interval Skor & Frekuensi & Persentase(\%) \\
\hline Faktor Pendapatan & $\begin{array}{l}\text { Tinggi } \\
\text { Sedang } \\
\text { Rendah }\end{array}$ & $\begin{array}{c}X \geq 15,006 \\
10,034 \leq X<15,006 \\
X \leq 10,034\end{array}$ & $\begin{array}{l}27 \\
39 \\
20\end{array}$ & $\begin{array}{l}31,39 \% \\
45,35 \% \\
23,26 \%\end{array}$ \\
\hline & Jumlah & & 86 & $100 \%$ \\
\hline Faktor Kekayaan & Tinggi & $X \geq 6,37$ & 17 & $19,76 \%$ \\
\hline Keluarga & $\begin{array}{l}\text { Sedang } \\
\text { Rendah } \\
\text { Jumlah }\end{array}$ & $\begin{array}{c}2,35 \leq x<6,37 \\
X<2,35\end{array}$ & $\begin{array}{l}53 \\
16 \\
86\end{array}$ & $\begin{array}{c}61,63 \% \\
18,60 \% \\
\mathbf{1 0 0 \%}\end{array}$ \\
\hline Faktor harga & $\begin{array}{l}\text { Tinggi } \\
\text { Sedang } \\
\text { Rendah } \\
\text { Jumlah }\end{array}$ & $\begin{array}{c}X \geq 15,39 \\
11,43 \leq x<15,39 \\
X<11,43\end{array}$ & $\begin{array}{l}41 \\
33 \\
12 \\
86\end{array}$ & $\begin{array}{c}47,67 \% \\
38,37 \% \\
13,95 \% \\
\mathbf{1 0 0 \%}\end{array}$ \\
\hline Faktor pola makan & $\begin{array}{l}\text { Tinggi } \\
\text { Sedang } \\
\text { Rendah } \\
\text { Jumlah }\end{array}$ & $\begin{array}{c}X \geq 15,39 \\
11,43 \leq x<15,39 \\
X<11,43\end{array}$ & $\begin{array}{l}49 \\
22 \\
15 \\
86\end{array}$ & $\begin{array}{c}56,97 \% \\
25,58 \% \\
17,44 \% \\
\mathbf{1 0 0 \%}\end{array}$ \\
\hline $\begin{array}{c}\text { Faktor sosial } \\
\text { budaya }\end{array}$ & $\begin{array}{l}\text { Tinggi } \\
\text { Sedang } \\
\text { Rendah } \\
\text { Jumlah }\end{array}$ & $\begin{array}{c}X \geq 22,89 \\
15,79 \leq x<22,89 \\
X<15,79\end{array}$ & $\begin{array}{l}19 \\
49 \\
18 \\
86\end{array}$ & $\begin{array}{c}22,1 \% \\
56,97 \% \\
20,93 \% \\
\mathbf{1 0 0} \%\end{array}$ \\
\hline $\begin{array}{c}\text { Faktor } \\
\text { pengetahuan gizi }\end{array}$ & $\begin{array}{l}\text { Tinggi } \\
\text { Sedang } \\
\text { Rendah } \\
\text { Jumlah }\end{array}$ & $\begin{aligned} X & \geq 13,93 \\
8,65 & \leq x<13,93 \\
X & <8,65\end{aligned}$ & $\begin{array}{l}26 \\
31 \\
29 \\
86\end{array}$ & $\begin{array}{c}30,23 \% \\
36,05 \% \\
33,72 \% \\
\mathbf{1 0 0 \%}\end{array}$ \\
\hline
\end{tabular}

koefisien regresi mempunyai nilai positif sebesar 0,238; maka dapat disimpulkan bahwa faktor pola makan berpengaruh positif terhadap pemilihan daging ayam broiler.

Daging ayam broiler merupakan bahan makanan yang sering dikonsumsi di masyarakat Kelurahan Tegalharjo. Pola makan daging ayam broiler pada rumah tangga di Kelurahan Tegalharjo ini dapat dikatakan tinggi, karena daging ayam broiler jumlahnya cukup banyak dan jenis makanan yang merupakan hasil olahan dari daging ayam broiler tidak sedikit jumlahnya.Berbagai jenis makanan olahan daging ayam broiler yang telah lama ada di lingkungan masyarakat Tegalharjo seperti satai ayam, soto ayam, ayam goreng, ayam bakar, opor ayam dll telah menjadi kebiasan yang turun temurun menjadi konsumsi harian masyarakat Tegalharjo.

Menurut Suharjo (1985), Pada umumnya cara makan masyarakat membentuk kerangka kerja dimana orang belajar tentang pangan dan mengembangkan kebiasaan makan pribadinya. Mempelajari cara yang berhubungan dengan konsumsi pangan dan menerima atau menolak bentuk atau jenis pangan tertentu, dimulai dari permulaan hidupnya dan menjadi bagian perilaku yang berakar diantara kelompok penduduk.

Faktorsosial budaya $\left(\mathrm{X}_{5}\right)$ berpengaruh positif terhadap keputusan memilih daging ayam broiler sebagai konsumsi Rumah Tangga di Kelurahan Tegalharjo Kecamatan Jebres Kota Surakarta. Hal ini dibuktikan dengan hasil statistik uji t untuk faktor sosial budaya diperoleh nilai t hitung sebesar 2,957 dan $\mathrm{t}$ tabel 1,671 ( $\mathrm{df}=85)$ dengan tingkat signifikansi 0,004; karena $\mathrm{t}$ hitung $>\mathrm{t}$ tabel $(2,957>1,671)$, signifikansi lebih kecil dari $0,05(0,004<0,05)$, dan koefisien regresi mempunyai nilai positif sebesar 0,174; maka dapat disimpulkan bahwa faktor sosial budaya berpengaruh positif terhadap pemilihan daging ayam broiler.

Lingkungan sosial masyarakat akan mempengaruhi budaya maupun adat istiadat setempat. Budaya tersebut biasanya terbentuk secara turun temurun dan telah mengakar pada masyarakat. Kegiatan budaya suatu keluarga, suatu kelompok masyarakat, suatu negara atau suatu bangsa mempunyai pengaruh yang kuat terhadap apa, kapan, dan bagaimana penduduk makan. Kebudayaan tidak hanya menentukan pangan apa, tetapi untuk siapa dan dalam keadaan bagaimana pangan tersebut dimakan (Suharjo, 1985). Beberapa contoh kegiaatan masyarakat yang telah membudaya seperti acara selamatan atau acara acara resmi lainnya seperti acara perkawinan, acara keluarga, hari raya dan lain-lain hampir bisa dipastikan terdapat makanan olahan daging ayam pada acara - acara tersebut. Acara acara tersebut secara langsung maupun tidak langsung sangat mempengaruhi sebuah keluarga dalam memilih daging ayam broiler.

Faktor pengetahuan gizi $\left(\mathrm{X}_{6}\right)$ berpengaruh positif terhadap keputusan memilih daging ayam broiler sebagai konsumsi Rumah Tangga di 
Tabel 7. Rangkuman hasil analisis regresi berganda

\begin{tabular}{lcccc}
\hline \hline Variabel & $\begin{array}{c}\text { Koefisien } \\
\text { regresi }(\mathrm{b})\end{array}$ & t-hitung & Sig & Kesimpulan \\
\hline Pendapatan Keluarga $\left(\mathrm{X}_{1}\right)$ & 0,584 & 6,614 & 0,000 & Signifikan \\
Kekayaan keluarga $\left(\mathrm{X}_{2}\right)$ & 0,20 & 0,180 & 0,859 & Tidak signifikan \\
Harga $\left(\mathrm{X}_{3}\right)$ & $-0,548$ & 4,939 & 0,000 & Signifikan \\
Pola Makan $\left(\mathrm{X}_{4}\right)$ & 0,238 & 3,282 & 0,002 & Signifikan \\
Sosial Budaya $\left(\mathrm{X}_{5}\right)$ & 0,174 & 2,957 & 0,004 & Signifikan \\
Pengetahuan Gizi $\left(\mathrm{X}_{6}\right)$ & 0,262 & 3,085 & 0,003 & Signifikan \\
\hline Konstanta & 6,959 & & \\
Adjusted $\mathrm{R}^{2}$ & 0,731 & & \\
F hitung & 39,483 & & \\
Sig & 0,000 & & \\
\hline Variabel terikat $=\mathrm{Y}($ Keputusan memilih daging ayam broiler) & & \\
\hline Sumber: Data Primer terolah, 2015 &
\end{tabular}

Sumber : Data Primer terolah, 2015

Kelurahan Tegalharjo Kecamatan Jebres Kota surakarta hal ini dibuktikan dengan hasil Hasil statistik uji t untuk faktor pengetahuan gizi diperoleh nilai t hitung sebesar 3,085 dan t tabel 1,671 $(\mathrm{df}=85)$ dengan tingkat signifikansi 0,003; karena $\mathrm{t}$ hitung $>\mathrm{t}$ tabel (3,085>1,671), signifikansi lebih kecil dari 0,05 $(0,003<0,05)$, dan koefisien regresi mempunyai nilai positif sebesar 0,262; maka dapat disimpulkan bahwa faktor pengetahuan gizi berpengaruh positif terhadap pemilihan daging ayam broiler.

Pengetahuan gizi berkaitan dengan pendidikan dan wawasan para ibu-ibu rumah tangga. Semakin tinggi tingkat pendidikannya maka semakin tinggi ilmu dan semakin luas wawasannya.Salah satu penyebab utama terjadinya gangguan gizi pada masyarakat adalah karena kurangnya pengetahuan tentang gizi atau kemampuan untuk menerapkan informasi tersebut dalam kehidupan sehari-hari (Suharjo, 1985).

Berdasarkan data hasil observasi yang dilakukan pada kepala keluarga di keluarahan Tegalharjo Kecamatan Jebres Kota Surakarta diketahui bahwa pendidikan mereka rata-rata SMA. Hal tersebut menandakan bahwa pendidikan responden dalam kategori menengah. Tingkat pendidikan yang sedang atau menengah ini memberikan sumbangan pengaruh kepada wawasan tentang pemenuhan gizi keluarga cukup bagus sehingga dalam menyajikan makan sudah mengarah kepada kualitas makanan yang bergizi.

\section{SIMPULAN}

Beberapa hal yang dapat disimpulkan dari penelitian mengenai faktor - faktor yang berpengaruh terhadap konsumsi daging ayam broiler di Surakarta, studi kasus di Kelurahan Tegalharjo, Kecamatan Jebres ini adalah sebagai berikut :

1. Keputusan kepala keluarga di Kelurahan Tegalharjo Kecamatan Jebres Kota Surakarta dalam memilih daging ayam broiler sebagai konsumsi rumah tangga dipengaruhi oleh faktor faktor sosial ekonomi berupa pendapatan keluarga, kekayaan, harga, pola makan, sosial budaya dan pengetahuan gizi .

2. Faktor-faktor ekonomi yang mempengaruhi keputusan seorang kepala keluarga untuk memilih daging ayam broiler sebagai konsumsi rumah tangga di Kelurahan Tegalharjo Kecamatan Jebres kota Surakarta adalah pendapatan keluarga dan harga.

3. Faktor ekonomi berupa kekayaan keluarga terbukti tidak memberikan pengaruh terhadap keputusan seorang kepala keluarga di Kelurahan Tegalharjo Kecamatan Jebres kota Surakarta dalam memilih daging ayam broiler sebagai konsumsi rumah tangga. Hal ini karena semakin kaya sebuah keluarga maka akan cenderung memilih daging yang mempunyai kualitas lebih baik.

4. Keputusan seorang kepala keluarga dalam memilih daging ayam broiler sebagai konsumsi rumah tangga di Kelurahan Tegalharjo Kecamatan Jebres Kota Surakarta juga dipengaruhi oleh faktor-faktor sosial berupa pola makan, sosial budaya dan pengetahuan gizi.

\section{DAFTAR PUSTAKA}

Arikunto, S. 2003. Prosedur Penelitian Suatu Pendekatan Praktek. Rineka Cipta. Jakarta

Badan Pusat Statistik. 2013. Rata-rata Per Kapita Beberapa Bahan Makanan Penting 2009-2012. http://www.bps.go.id. Dikases pada hari Rabu, 26 Juni 2014.

Berg, A. 1986. Peranan Gizi Dalam Pembangunan Nasional. Rajawali. Jakarta.

Direktorat Jendral Peternakan dan Kesehatan Hewan. 2012. Daging Ayam Sumber Makanan Bergizi. Kementrian Pertanian. Jakarta.

Hakim, A. 2008. Pengaruh Variabel Makro Terhadap Pola Konsumsi Masyarakat Indonesia. http://www.scribd.com/doc. Dikases pada hari Rabu, 26 Juni 2014.

Kotler, P. 1994. Marketing Management: Analysis, Planing, Implementation, Control. Ed. 8, New jersey: Prentice Hall, Inc. 
Lipsey, R.G., Paul, N. Courant, D. Pumis, dan P.O. Steiner. 1995. Ekonomi Mikro. Bina Rupa Aksara. Jakarta.

Mardikanto, T. 2001. Prosedur Penelitian Penyuluhan Pembangunan. Prima Pressindo. Surakarta.

Muhidin, S. A. 2007. Analisis Korelasi, Regresi dan Jalur dalam Penelitian. Pustaka Setia. Bandung.

Santoso, S. 2004. Buku Latihan SPSS Statistika. Elex Media Komputindo. Jakarta.

Sugiyono. 2004. Statistika Untuk Penelitian. Alfabeta. Bandung.

Suhardjo. 1985. Pangan Gizi dan Pertanian. Universitas Indonesia Press. Jakarta. 